\title{
COMPARATIVE ANALYSIS OF THE CURRICULUM OF MECHANICAL ENGINEERING PROGRAM IN POLAND AND THE UNITED STATES
}

\author{
Wes GREBSKI ${ }^{1}$, Michalene GREBSKI ${ }^{2}$, Agnieszka CZERWIŃSKA-LUBSZCZYK ${ }^{3 *}$, \\ Dominika JAGODA-SOBALAK ${ }^{4}$ \\ ${ }^{1}$ The Pennsylvania State University, USA; wxg3@psu.edu, ORCID: 0000-0002-4684-7608 \\ ${ }^{2}$ Northampton Community College, USA; mgrebski.northampton.edu, ORCID: 0000-0002-3487-4473 \\ ${ }^{3}$ University of Technology and Humanities in Bielsko-Biała, Poland; aczerwinska@ath.bielsko.pl, \\ ORCID: 0000-0001-8100-8802 \\ ${ }^{4}$ Opole University of Technology, Poland; d.jagoda@po.opole.pl, ORCID: 0000-0003-3085-6603 \\ * Correspondence author
}

Purpose: The aim of this paper is comparison of the Curriculum of Mechanical Engineering Program in Poland and the United States. One of the institutions is The Pennsylvania State University (PSU), in the United States (USA). The other institution is Politechnika Opolska (PO), in Poland.

Design/methodology/approach: Desk Research Method is used. Paper is based on Politechnika Opolska' documents and The Pennsylvania State University' documents.

Findings: The paper addresses the similarities and differences in both curricula. It also addresses the positive and negative aspects of both curricula. The strengths and weaknesses from the perspective of the future career development of graduates is also being addressed. Both Mechanical Engineering programs are striving for excellence in preparing students for engineering jobs in industry, but the philosophy of those programs is very different. The Mechanical Engineering program at PSU is providing the student with a stronger theoretical background. Graduates from the PO program are well-trained in application-focus current industry practices. They are not going to require on-the-job training after entering industry. There are also suggestions and recommendations for both programs from the perspective of identifying the best practices.

Originality/value: The article contains a comparative analysis of the curricula of the Mechanical Engineering program at The Pennsylvania State University USA and Politechnika Opolska, Poland. The comparison of the curricula was done using the most recent catalogs of both programs. The authors of the article have had experience as faculty at their respective programs. The comparative analysis was done for the purpose of identifying the best practices and subsequent follow-up. The article addresses the similarities and differences as well as the strengths and weaknesses of both programs. The article also contains suggestions and recommendations for both programs.

Keywords: Curriculum development, engineering curriculum, mechanical Engineering.

Category of the paper: Research paper. 


\section{Introduction}

Higher education is a crucial sector for transfer of knowledge and innovation. The education process, innovation in teaching and the graduates' integration into the labor market are important for regional economic development and contribute towards building dynamic environment for innovation. The learning environment is continuously changing. This requires a constant revision of the teaching methodology and analysis of the curriculum (Epure, 2017; Duever, 2019; Rampersad, 2015).

The aim of this paper is comparison of the curriculum of the Mechanical Engineering program in Poland and the United States. Statistical data from Organisation for Economic Cooperation and Development (OECD) confirm that, indicators like: mathematical performance (measures the mathematical literacy of a 15 year-old to formulate, employ and interpret mathematics in a variety of contexts to describe, predict and explain phenomena, recognizing the role that mathematics plays in the world), reading performance (measures the capacity to understand, use and reflect on written texts in order to achieve goals, develop knowledge and potential, and participate in society) and scientific performance (use of scientific knowledge to identify questions, acquire new knowledge, explain scientific phenomena, and draw evidence-based conclusions about science-related issues) - are higher value for Poland than for USA (OECD). On the other hand, according to The Global Competitiveness Report 2018 published by The World Economic Forum, assessing the competitiveness of economies, the USA is a pioneer (overall score), Poland - rank 37 (Schwab, 2018). It is necessary to find a way to improve this situation. One of possibility could be higher education adjusting curriculum to changes in the environment.

Engineering is an application-focused discipline. It used to be very practical. Before the Engineering programs at the university-level were created, engineers were trained in a tradeapprenticeship program. Designing, analyzing and building an invention was done by the same person or team under the supervision of the master. By the 1970's, engineering programs in the USA were coming very scientific and theoretical. While the engineering programs were becoming very theoretical, there was a need in industry for practically trained professionals. To satisfy this need, many educational institutions started Engineering Technology programs for the purpose of training hands-on engineers. Many educational institutions in the USA offer simultaneously Engineering and Engineering Technology programs targeting two different job markets. There is a significant overlap between the Engineering and Engineering Technology curricula.

Desk Research Method is used. Paper is based on Politechnika Opolska' documents (Study Plans...) and The Pennsylvania State University' documents (Program description...). 


\section{Theoretical background}

The learning environment is continuously changing and causes modifications on every level of education (Martínez-Medina, and Arrebola, 2019; Saraiva et al., 2019). Martínez-Prado et al. (2018) noticed "technological changes require a new and different set of skills every time a novel technique raises; this involves updating the academic curricula every few years". For example, emerging technologies referred to as 'fourth industrial revolution' have prompted many to develop student's socio-technical skills (Trevelyan, 2019). Demand from employers for graduates' skills are also modified. This requires a constant revision of the textbooks, tools (software and hardware), courses teaching methodology (Bennedsen et. al. 2018; Litster et. al., 2020) and analysis of the curriculum (Epure, 2017; Rampersad, 2015). For example, MartínezPrado et. al. (2018) focused on using a robot motion controller for an undergraduate laboratory study program. Stammes et al. (2020) highlight design practices in education. It is a way to engage students in "applying science concepts, in developing soft skills, and in applying or developing research practices". White et all (2020), emphasized "training undergraduates in experimental design and data analysis/presentation skills especially as it applies to living systems". Cameron and Birkett (2020) proposed Process Systems Engineering concepts, as approaches for updating higher education curricula.

Nowadays engineering curricula should contains many aspects of business reality, such as ethical, ecological, cultural, safety, etc. Bairaktarova and Pilotte (2019) noticed that "engineering practice is meant to advance the human condition, yet curricula do not appear to fully promote the human-centered philosophy of engineering in implementation". Hoven (2019) noted aspect of comprehensive engineering. "Comprehensive engineering implies ethical coherence, consilience of scientific disciplines, and cooperation between parties" (Hoven, 2019; Taebi, and Kastenberg, 2019). Jordan et al. (2019) focused on cultural aspects connected with engineering work. They indicated the necessity to develop culturally responsive engineering curriculum. Gunasekera et al. (2020) focused at safety in engineering education. Safety is an one of important area and the nowadays the trends in environmental safety promote this. It is extremely important in engineering work for example identify hazards connected with equipment design due to specification of this equipment, its type, process conditions, substances involved et al.

Sustainability has emerged as a new area of interest. Sustainability concentrates on the interactions between nature and society (Sánchez-Carracedo et al., 2019; Salovaara, Soini, and Pietikäine, 2019). For example, Durrans et al. (2020) noticed "there is an urgent need for educational institutions to produce graduates with appropriate skills to meet the growing global demand for professionals in the sustainable energy industry". Research results (Vargas et al., 2019) suggested that policy frameworks for sustainable development implementation should include "collaboration, partnership, education, outreach, teaching and learning, staff 
development, curriculum review, research, campus operations and policy". It requires developing the fields of management, research and development, teacher evaluation as well as changing academic programs (Tejedor et al., 2019; Weng, Liu, and Chuang, 2019).

Peña and Ballesteros (2016) brings attention to "the gulf that exists between the academic system and the needs of businesses" and highlight "the lack of a genuine climate of cooperation as identified as one of the causes". Litster et al. (2020) highlight the cooperation between both academia and industry to achieve a significantly higher percentage of engineers trained in engineering science. Working knowledge and practicality of engineering design prepares students for embracing the challenges of the future. To support students in developing these capabilities, teachers are tasked with the responsibility of facilitating science instruction that integrates science and engineering practices (Brand, 2020). Brand (2020) focused on factors that motivated teachers to reform their instructional practices. His results indicate, it is necessary the need to shift teaching philosophies related to teacher's learning environments and their instructional practices.

\section{Results}

\subsection{Comparative analysis of the foundation courses}

Foundation courses for Engineering programs are Mathematics, Physics and Chemistry. The comparison of the curricula requirements in those areas for the two curricula are shown in Table 1. To compare the courses, it was necessary to adapt the same method for calculating the number of credit hours that students are granted for the course. The method used in the USA is based on the number of hours spent in the classroom according to the policy as follows:

- 15 hours of lecture is equivalent to 1 credit,

- 30 hours of lab is equivalent to 1 credit.

No credits are given in the USA for consultation time or the work that the student does on their own time. Credits are given only for the time of direct contact. European credits (ECTS) include the time that the student is spending after class time. Course outlines for Politechnika Opolska (PO) list the number of hours for direct contact. It was relatively easy to calculate the number of credit hours used by the system at The Pennsylvania State University (PSU). The PSU Admissions Office is doing this if the student transfers from European to a USA university.

Comparing the requirements in the foundation courses (Mathematics, Physics and Chemistry), it is obvious that the Mechanical Engineering program at PSU is more theoretical than the Mechanical Engineering program at PO. The Mechanical Engineering program at PO is more application focused and equivalent to the Mechanical Engineering Technology 
program in the PSU system. This will be discussed in greater detail when a comparison is made of the technical courses.

Table 1.

Curricula requirements in foundation courses

\begin{tabular}{|c|c|c|c|}
\hline \multicolumn{2}{|c|}{$\begin{array}{c}\text { The Pennsylvania State University } \\
\text { United States }\end{array}$} & \multicolumn{2}{|c|}{$\begin{array}{c}\text { Politechnika Opolska } \\
\text { Poland }\end{array}$} \\
\hline \multicolumn{2}{|c|}{ Mathematics } & \multicolumn{2}{|c|}{ Mathematics } \\
\hline Course & Credits & Course & Credits \\
\hline $\begin{array}{l}\text { Calculus I } \\
\text { MATH } 140\end{array}$ & 4 & $\begin{array}{l}\text { Pre-calculus } \\
\text { MATH } 1\end{array}$ & 3 \\
\hline $\begin{array}{l}\text { Calculus II } \\
\text { MATH } 141\end{array}$ & 4 & $\begin{array}{l}\text { Calculus I } \\
\text { MATH } 2\end{array}$ & 1.5 \\
\hline $\begin{array}{l}\text { Differential Equations } \\
\text { MATH } 251\end{array}$ & 4 & $\begin{array}{l}\text { Calculus II } \\
\text { MATH }\end{array}$ & 1.5 \\
\hline $\begin{array}{l}\text { Calculus of Several Variables } \\
\text { MATH } 231\end{array}$ & 2 & & \\
\hline $\begin{array}{l}\text { Matrices } \\
\text { MATH } 220\end{array}$ & 2 & & \\
\hline \multicolumn{2}{|l|}{ Physics } & \multicolumn{2}{|c|}{ Physics } \\
\hline $\begin{array}{l}\text { Mechanics } \\
\text { PHYS } 211 \\
\end{array}$ & 4 & $\begin{array}{l}\text { General Physics } \\
\text { PHYS }\end{array}$ & 1.5 \\
\hline $\begin{array}{l}\text { Electricity and Magnetism } \\
\text { PHYS } 212\end{array}$ & 4 & & \\
\hline $\begin{array}{l}\text { Quantum Mechanics } \\
\text { PHYS } 214\end{array}$ & 2 & & \\
\hline \multicolumn{2}{|c|}{ Chemistry } & \multicolumn{2}{|c|}{ Chemistry } \\
\hline $\begin{array}{l}\text { General Chemistry } \\
\text { CHEM } 110\end{array}$ & 3 & $\begin{array}{l}\text { General Chemistry } \\
\text { CHEM }\end{array}$ & 1.5 \\
\hline $\begin{array}{l}\text { Chemistry Lab } \\
\text { CHEM } 111\end{array}$ & 1 & & \\
\hline $\begin{array}{l}\text { Organic Chemistry } \\
\text { CHEM } 112\end{array}$ & 3 & & \\
\hline
\end{tabular}

\subsection{Comparative analysis of common technical courses}

Technical courses in both programs have their equivalency as shown in Table 2.

Table 2.

Equivalent courses in the Mechanical Engineering programs of The Pennsylvania State University and Politechnika Opolska

\begin{tabular}{|l|c|l|c|}
\hline \multicolumn{1}{|c|}{$\begin{array}{c}\text { The Pennsylvania State University } \\
\text { (Technical Courses/Credits) }\end{array}$} & \multicolumn{1}{c|}{$\begin{array}{c}\text { Politechnika Opolska } \\
\text { Course }\end{array}$} & Credits & \multicolumn{1}{c|}{ Course } \\
\hline \multicolumn{1}{|c|}{ Credits } \\
\hline $\begin{array}{l}\text { Computer Science } \\
\text { SMPSC 200 }\end{array}$ & 3 & Information Technology & 2 \\
\hline $\begin{array}{l}\text { Statistics } \\
\text { E MCH 211 }\end{array}$ & 3 & Numerical Methods & 2 \\
\hline $\begin{array}{l}\text { Dynamics } \\
\text { E MCH 212 }\end{array}$ & 3 & Mechanics & 1.5 \\
\hline $\begin{array}{l}\text { Strength of Materials } \\
\text { E MCH 213 }\end{array}$ & 3 & Mechanics & 3 \\
\hline $\begin{array}{l}\text { Engineering Design and Graphics } \\
\text { EDSGN 100 }\end{array}$ & 3 & Strength of Materials & 3 \\
\hline
\end{tabular}


Cont table 2.

\begin{tabular}{|c|c|c|c|}
\hline $\begin{array}{l}\text { Engineering Thermodynamics } \\
\text { ME } 300\end{array}$ & 3 & $\begin{array}{l}\text { Descriptive Geometry of Engineering } \\
\text { Graphics }\end{array}$ & 3 \\
\hline $\begin{array}{l}\text { Product Design and Manufacturing } \\
\text { Processes } \\
\text { IE } 312\end{array}$ & 3 & Thermodynamics & 3.5 \\
\hline $\begin{array}{l}\text { Properties and Processes of } \\
\text { Engineering } \\
\text { Materials } \\
\text { MATSE } 259\end{array}$ & 3 & Machining Processes & 3 \\
\hline $\begin{array}{l}\text { Computational Tools } \\
\text { ME } 300\end{array}$ & 3 & Material Science & 1.5 \\
\hline $\begin{array}{l}\text { Circuit Analysis, Instrumentation, } \\
\text { Statistics } \\
\text { ME } 348\end{array}$ & 3 & $\begin{array}{l}\text { Elements of Information and Computer } \\
\text { Technology }\end{array}$ & 3 \\
\hline $\begin{array}{l}\text { Academics and Career Development } \\
\text { ME } 390\end{array}$ & 0.5 & Electrical Engineering & 1.5 \\
\hline $\begin{array}{l}\text { Mechatronics } \\
\text { ME } 454\end{array}$ & 3 & Industrial Practice & 0.5 \\
\hline $\begin{array}{l}\text { Mechanical Engineering Design } \\
\text { ME } 340\end{array}$ & 3 & Selected Measuring Technology & 3 \\
\hline $\begin{array}{l}\text { Mechanical Design } \\
\text { ME } 360\end{array}$ & 3 & Technological Process Design & 4 \\
\hline $\begin{array}{l}\text { Fluid Mechanics } \\
\text { ME } 320\end{array}$ & 3 & Mechanical Engineering Design & 4 \\
\hline $\begin{array}{l}\text { Professional Development of } \\
\text { Mechanical } \\
\text { Engineers } \\
\text { ME } 490\end{array}$ & 0.5 & Fluid Mechanics & 3 \\
\hline & & Protecting Intellectual Properties & 1 \\
\hline & & Materials Engineering & 2 \\
\hline & & Automation Robotics & 3 \\
\hline & & Engineering Graphics with CAD & 2 \\
\hline
\end{tabular}

Many courses offered in the Mechanical Engineering program at PO do not have any equivalent or similar courses at PSU. Those courses are listed in Table 3.

Table 3.

Courses offered at Politechnika Opolska not having equivalency to The Pennsylvania State University System

\begin{tabular}{|l|c|}
\hline \multicolumn{1}{|c|}{ Courses } & Credits \\
\hline CAD I & 0.5 \\
\hline CAD II & 0.5 \\
\hline CAD III & 0.5 \\
\hline CAD IV & 0.5 \\
\hline CAD V & 0.5 \\
\hline CAD & 2 \\
\hline Ergonomics and Industrial Safety & 1 \\
\hline Techniques for Generating Energy & 2 \\
\hline Technology of Industrial Operations & 2 \\
\hline Technical Metrology & 1 \\
\hline Basics of Ecology & 1 \\
\hline Machines & 2 \\
\hline Combustion Engines & 3 \\
\hline
\end{tabular}


Cont table 2.

\begin{tabular}{|l|c|}
\hline Machine Reliability or & 2 \\
Quality Control & 2 \\
\hline Material Shaping & 3 \\
\hline Technological Machines & 2.5 \\
\hline Machine Propulsion & 2.5 \\
\hline Machine Control Techniques or & 2.5 \\
CNC Programming & 2 \\
\hline Maintenance of Vehicles and Machines & 3 \\
\hline Techniques of Welding & 3 \\
\hline Unconventional Manufacturing Techniques & 2.5 \\
\hline Preparing Technical Documentation & 3 \\
Final Element Analysis & 2 \\
or & \\
Technical Instrumentation & 3 \\
Production Management & 2 \\
\hline Vehicle and Mobile Machines & 3 \\
Construction and Maintenance of Individual Apparatus & 3 \\
Diagnostic of Machines & 3 \\
Construction of Refrigeration Systems & 2.5 \\
or & \\
Technology of Machines and Equipment Repair & 3 \\
Apparatus Manufacturing and Technology & 3 \\
Theory of Mechanisms and Machines & 2.5 \\
Computer-Aided Chipless Technologies & 2.5 \\
\hline
\end{tabular}

As shown in Table 3, the Mechanical Engineering program at PO requires students to take many very detailed specialized courses. The purpose is to better prepare students to enter a diverse job market in industry. This allows graduate to rapidly meet the demands of industry after finding employment. This characteristic is very typical of Mechanical Engineering Technology programs preparing graduates to enter the job market without the need for additional on-the-job training. The Mechanical Engineering program at PSU also offers some courses which do not have any equivalency to the Mechanical Engineering program at PO as shown in Table 4.

Table 4.

Courses offered by The Pennsylvania State University not having equivalency in the Politechnika Opolska system

\begin{tabular}{|l|c|}
\hline \multicolumn{1}{|c|}{ Courses } & Credits \\
\hline Vibration of Mechanical Systems & 3 \\
ME 370 & 3 \\
\hline Heat Transfer & 3 \\
ME 410 & 3 \\
\hline $\begin{array}{l}\text { Modeling of Dynamic Systems } \\
\text { ME 450 }\end{array}$ & \multirow{2}{*}{14} \\
\hline Engineering Technical Elective & \\
\hline
\end{tabular}


The courses like Vibration in Mechanical Systems or Modeling of Dynamic Systems as well as fourteen credits in technical electives are very theoretical and mathematically oriented. In general, the courses offered in the Mechanical Engineering program at PSU are more theoretical and more general in nature. Graduates from that program get a stronger theoretical preparation and have a much weaker preparation in application-focused concepts. As a result, graduates from the Mechanical Engineering program at PSU will require one-to-two years of on-the-job training after entering a position in industry. By having a stronger theoretical background, however, they can be more diverse and adaptable to the constantly changing demands of knowledge-based industries.

\subsection{Comparative of general education courses}

General Education courses support the technical courses and provide students with the soft skills needed to work in the engineering profession. Both engineering programs offer general education courses as shown in Table 5.

Table 5.

Comparison of the general education requirements The Pennsylvania State University and Politechnika Opolska

\begin{tabular}{|l|c|c|c|}
\hline \multicolumn{2}{|c|}{$\begin{array}{c}\text { The Pennsylvania State University } \\
\text { United States (USA) }\end{array}$} & \multicolumn{2}{c|}{$\begin{array}{c}\text { Politechnika Opolska } \\
\text { Poland }\end{array}$} \\
\hline \multicolumn{1}{|c|}{ Course } & Credits & N/A & Credits \\
\hline $\begin{array}{l}\text { Rhetoric and Composition } \\
\text { ENGL 15 }\end{array}$ & 3 & N/A & N/A \\
\hline $\begin{array}{l}\text { Technical Writing } \\
\text { ENGL 202C }\end{array}$ & 3 & Humanities/Social Science* & 5 \\
\hline $\begin{array}{l}\text { Speech Communication } \\
\text { CAS 100 }\end{array}$ & 3 & $*$ & \\
\hline Humanities Electives & 6 & N/A & 1 \\
\hline Social Science Electives & 3 & Physical Education & 4 \\
\hline Freshman Seminar & 1 & Foreign Language & \\
\hline Physical Education & 3 & N/A & \\
\hline Foreign Language & & & \\
\hline
\end{tabular}

Notes:

* Students may take a combination of Humanities and/or Social Science electives for a total of 5 credits.

N/A: Not applicable.

The Mechanical Engineering program at PSU requires more courses in the General Education category. Rhetoric and Composition in English as well as Technical Writing and Communication are required at PSU. Those courses are normally assessed as very important by former graduates and their employers. Every engineering student is also required to take an Economics course, either Microeconomics or Macroeconomics. Those skills are needed to communicate effectively with the business world either in applying for grants or justifying investments. Students are also required to take two arts courses, two humanities courses and one social science course. Those graduates make the graduates well-rounded individuals who understand the non-technical aspects of the world better. Every student at PO is also required 
to take humanities, social science and foreign language courses. However, there are no courses in technical writing as well as oral and written communication.

\subsection{Comparative analysis of technical electives}

The Mechanical Engineering program at PSU has fourteen credits (average five courses) of technical elective requirements as shown in Table 3. Those technical electives allow students to pursue their own interests and to specialize in the area of the student's interest. If the students know their employment goals, they may take technical electives which will help them to meet those goals.

The Mechanical Engineering program at PO has two tracks. Elective courses are based on the track chosen by the student. After the track was chosen, the student has limited choices in course selection. The strength of that approach is that every graduate will have the same training and background. The weakness of that approach is the lack of flexibility in customizing the students' educational background.

\section{Summary - similarities and differences}

Both Mechanical Engineering programs offered at PSU and PO are striving for excellence in preparing students for engineering jobs in industry. The philosophy of those programs is very different. The Mechanical Engineering program at PSU is providing the student with a stronger theoretical background in Mathematics, Physics, Chemistry and fundamental engineering courses. The PSU program does not have significant application components reflecting industrial practices. The application-focused component will be learned during the first years of employment. Graduates will learn precisely what they need to know to handle the responsibilities of the job for which they were hired.

The Mechanical Engineering program at PO is more like the Mechanical Engineering Technology at PSU. Graduates from the PO program are well-trained, focusing on current industry practices. They are not going to require on-the-job training after entering industry. These are different philosophies of those two programs.

\section{Discussion}

The aim of this paper is comparison of the Curriculum of Mechanical Engineering Program in Poland and the United States. Both Mechanical Engineering programs represent different approaches to engineering education. Some industries prefer to hire Engineering Technology 
graduates because of their application-focused background. Often there are voices in industry that feel that this is the better approach to engineering education. Some industries prefer to hire Engineering graduates because they have a more theoretical background and have a higher diversity of skills. Many people in industry believe that a stronger theoretical background is more valuable in the knowledge-based economy because a theoretical background never becomes obsolete. Industrial processes can change and quickly become obsolete. Presently there are jobs for graduates from both programs. It is important to collect feedback from industry and constantly adjust program educational objectives based on the demands of industry.

The next step of the research could be a more complex analysis of lecture content (e.g. ethical, ecological, safety, cultural aspects) and results of education (e.g. knowledge, soft skills, competence).

The comparative analysis will require a study of internal and external environment in both countries. It is necessary to pay attention to the differences e.g. financing the education, model of university-industry cooperation, political, economic, social, technological and ecological factors (Czerwińska et. al., 2019). Due to the length of the article, these differences were not provided.

\section{References}

1. Bairaktarova, D.N., and Pilotte, M.K. (2019). Person or thing oriented: A comparative study of individual differences of first-year engineering students and practitioners. Journal of Engineering Education, Vol. 109, pp. 230-242.

2. Bennedsen, J., Rouvrais, S., Roslöf, J., Kontio, J., Georgsson, F., and McCartan, C.D. (2018). Collaborative quality enhancement in engineering education: an overview of operational models at a programme level. European Journal of Engineering Education, pp. 1-20.

3. Brand, B.R. (2020). Integrating science and engineering practices: outcomes from a collaborative professional development. International Journal of STEM Education, Vol. 7, Iss. 13, pp. 1-13.

4. Cameron, I., and Birkett, G. (2020). Journey Making: Applying PSE Principles to Complex Curriculum Designs. Processes, Vol. 8, pp. 1-13.

5. Czerwińska-Lubszczyk, A., Grebski, M. and Jagoda-Sobalak, D. (2019). Współpraca uczelni z przemysłem - finansowanie i realizacja prac naukowo-badawczych w Polsce i w USA. Systemy Wspomagania w Inżynierii Produkcji, Górnictwo - perspektywy, zagrożenia, Vol. 8, Iss. 1, pp. 35-50. 
6. Duever, T.A. (2019). Data Science in the Chemical Engineering Curriculum. Processes, Vol. 7, pp. 1-7.

7. Durrans, B., Whale, J., and Calais, M. (2020). Benchmarking a Sustainable Energy Engineering Undergraduate Degree against Curriculum Frameworks and Pedagogy Standards from Industry and Academia. Energies, Vol. 13, pp. 1-32.

8. Epure, M. (2017). University-business cooperation: adapting the curriculum and educational package to labor market requirements. Proc. of the International Conference on Business Excellence, Vol. 11, Iss. 1, pp. 339-349.

9. Gunasekera, M., Ahmed, S., and Khan, F. (2019). Integration of process safety in equipment design: A framework for academic learning activity, Education for Chemical Engineers, Vol. 30, pp. 32-39.

10. Hoven, J. (2019). Ethics and the UN Sustainable Development Goals: The Case for Comprehensive Engineering Commentary on "Using Student Engagement to Relocate Ethics to the Core of the Engineering Curriculum". Science and Engineering Ethics, Vol. 25, pp. 1789-1797.

11. Jordan, S.S, Foster, C.H., Anderson, I.K., Betoney, C.A., and Pangan, T.J.D. (2019). Learning from the experiences of Navajo engineers: Looking toward the development of a culturally responsive engineering curriculum. Journal of Engineering Education, Vol. 108, pp. 355-376.

12. Litster, J.D., Michaels, J.N., and Jacob, K.V. (2020). Particle technology education in the 21st century - Outcomes from the IFPRI sponsored workshop in Sheffield, April 2017. Powder Technology, Vol. 366, pp. 144-149.

13. Martínez-Medina, R., and Arrebola, J.C. (2019). Analysis of Sustainability Activities in Spanish Elementary Education Textbooks. Sustainability, Vol. 1, pp. 1-14.

14. Martínez-Prado, M.A., Rodríguez-Reséndi, J., Gómez-Loenzo, R.A., Camarillo-Gómez K.A., and Herrera-Ruiz, G. (2018). Short informative title: Towards a new tendency in embedded systems in mechatronics for the engineering curricula. Computer Applications in Engineering Education, Vol. 27, pp. 603-614.

15. OECD, www.data.oecd.org, 20.11.2019.

16. Peña F.A.V., and Ballesteros J.H. (2016). University Internships in Spain: What is Missing for its Stakeholders? Revista de Ciencias Sociales, Vol. 11, Iss. 2, pp. 547-566.

17. Program description, Mechanical Engineering, B.S. (engineering), Penn State, 2019.

18. Rampersad, G.C. (2015). Developing university-business cooperation through workintegrated learning. International Journal of Technology Management, Vol. 68, Iss. 3-4, pp. 203-227.

19. Salovaara, J.J., Soini, K., and Pietikäine, J. (2019). Sustainability science in education: analysis of master's programmes' curricula. Sustainability Science, Vol. 15., pp. 1-15.

20. Sánchez-Carracedo, F., Moreno-Pino, F.M., Sureda, B., Antúnez, M., and Gutiérrez, I. (2019). A Methodology to Analyze the Presence of Sustainability in Engineering Curricula. 
Case of Study: Ten Spanish Engineering Degree Curricula. Sustainability, Vol. 11, pp. 1-27.

21. Saraiva, T.S., Almeida, M., Bragança, L., and Barbosa, M.T. (2019) Verification of the Adequacy of the Portuguese Sustainability Assessment Tool of High School Buildings, SAHSBPT, to the Francisco de Holanda High School, Guimarães. Sustainability, Vol. 1, pp. 1-21.

22. Schwab, K. (2018). The Global Competitiveness Report 2018. Geneva: The World Economic Forum.

23. Stammes, H., Henze, I., Barendsen, E., and de Vries M. (2020). Bringing design practices to chemistry classrooms: studying teachers' pedagogical ideas in the context of a professional learning community. International Journal of Science Education, Vol. 42, Iss. 4, pp. 526-546.

24. Study Plans and Programs, Mechanical Engineering, First Cycle Programme, Full-time studies, Politechnika Opolska, 2017.

25. Taebi, B., and Kastenberg, W. (2019). Teaching Engineering Ethics to PhD Students: A Berkeley-Delft Initiative Commentary on "Ethics Across the Curriculum: Prospects for Broader (and Deeper) Teaching and Learning in Research and Engineering Ethics". Sci Eng Ethics, Vol. 25, pp. 1763-1770.

26. Tejedor, G., Segalàs, J., Barrón, Á., Fernández-Morilla M., Teresa Fuertes, M., RuizMorales, J., Gutiérrez, I., García-González, E., Aramburuzabala, P., and Hernández À. (2019). Didactic Strategies to Promote Competencies in Sustainability. Sustainability, Vol. 11, pp. 2-24.

27. Trevelyan, J. (2019). Transitioning to engineering practice. European Journal of Engineering Education, Vol. 44, Iss. 6, pp. 821-837.

28. Vargas, V.R., Lawthom, R., Prowse, A., Randles, S., and Tzoulas, K.: Implications of Vertical Policy Integration for Sustainable Development Implementation in Higher Education Institutions. Journal of Cleaner Production, Vol. 235, Iss. 20, pp. 733-740.

29. Weng, S-S., Liu, Y., and Chuang, Y-C. (2019). Reform of Chinese Universities in the Context of Sustainable Development: Teacher Evaluation and Improvement Based on Hybrid Multiple Criteria Decision-Making Model. Sustainability, Vol. 11, pp. 1-23.

30. White, J.A., Gaver, D.P., Butera, JR., et al (2020). Core Competencies for Undergraduates in Bioengineering and Biomedical Engineering: Findings, Consequences, and Recommendations. Annals of Biomedical Engineering, Vol. 48, Iss. 3, pp. 905-912. 